\title{
The American Background of Loyalist Slaves
}

Harvey Amani Whitfield

\section{Introduction}

This article examines the experience of Loyalist slaves before leaving the American colonies for Maritime Canada during and after the Revolutionary War. It seeks to understand the lives of Loyalist slaves before the war and the types of experiences, work patterns, traditions, and cultures they brought to Nova Scotia, New Brunswick, Cape Breton, and Prince Edward Island after 1783. This article demonstrates that Loyalist slaves cannot be understood as a single homogenous group, rather they must be seen as a diverse set of slaves who had incredibly different and complex experiences before arriving in Maritime Canada. As the following personal experiences indicate, this diversity of Loyalist slaves emerges from even the most fragmentary evidence. ${ }^{1}$

In 1783, twenty-six year old Dinah boarded the Apollo destined for Shelburne, Nova Scotia. She did not travel with any family members. Alongside her were three other African Americans who had achieved freedom during the Revolutionary War. As these men wondered about the type of freedom that awaited them in Nova Scotia, Dinah remained enslaved. ${ }^{2}$ She had labored in New York City for grocer Robert Wilkins along with two other "servants" whose status and race are unclear. ${ }^{3}$ After arriving in Shelburne, Dinah continued to work for Wilkins until the summer of 1786 when "she went away" wearing "a blue and white Ticking Petticoat, a purple and white Callico short Gown, and an old blue Cloak."

Eight-year-old Venus's owner John Herbert made the fateful decision to support Lord Dunmore and those Virginians still loyal to His Majesty. Her master had been a well-to-do shipbuilder in Norfolk who also owned two plantations including one of 500 acres. ${ }^{5}$ Although some black Virginians had obtained freedom by fleeing to Lord Dunmore, John Herbert's loyalty resulted in Venus remaining enslaved. Venus eventually migrated to New York City and found herself on board the Esther in 1783. " Herbert's other slaves accompanied Venus to Shelburne. Once in Nova Scotia, Venus worked for her owner as a domestic servant and probably aided his business as a ship's carpenter and painter. She served Herbert until his death in 1799 and continued as a slave to his wife during the early nineteenth century.

Pompey Chase had been the property of Bostonian Jacob Sharpe, who 
sold him to Reuben Chase of Fredericksburg, New York. Chase worked as a tenant farmer who eventually abandoned New York for New Brunswick. During the Loyalist evacuation, Pompey boarded the Sovereign and found himself surrounded by people of African descent from various points of the Atlantic world. For the most part, these men and women had experienced American slavery. Although Pompey shared their past, his future would be markedly different as he remained the only still enslaved individual on the Sovereign. ${ }^{7}$ The realization that his brethren were free, while his labor still belonged to another man, must have been excruciatingly painful. In his late twenties, Pompey probably had a close relationship with his master, who did not bring any other slaves to Maritime Canada.

The stories of Dinah, Venus, and Pompey undercut the traditional narrative of Black Loyalist historiography, which emphasizes the movement of African Americans from slavery to freedom. ${ }^{8}$ For example, Venus went from slavery in the American colonies to continued enslavement in Shelburne, Nova Scotia. The personal histories of these slaves also tell another important story: that Loyalist slaves in Maritime Canada came from multiple backgrounds and diverse experiences. They worked on farms, but also as domestic laborers; Loyalist slaves ranged in age, and included infants and the elderly; some came with family and without; some possessed various skills, while others only knew the tedious drill of field labour. The fact that they came from such different regions of the American colonies meant that their experience and understanding of what it meant to be a slave varied dramatically.

The slaves of American Loyalists originated from three distinct regions: The North, the Chesapeake, and the Lowcountry. The majority came from New England and the Middle Colonies, which reflected the general makeup of Loyalist migration to the Maritimes. ${ }^{9}$ Yet, as historian Carole Watterson Troxler shows, a smaller contingent came from the southern colonies. ${ }^{10}$ Loyalist slaves reflected general trends associated with colonial American slavery in terms of work and culture. But, their fate to become Loyalist slaves made them unique in the pantheon of American slave history, as they experienced the massive upheaval of migration coupled with the chaos of resettlement in postwar Maritime Canada. This uniqueness is grounded in their transition from American slaves to Loyalist slaves, which can be understood in terms of change and continuity. These African Americans experienced change due to forced migrations from their original homes to occupied New York City and finally to Maritime Canada. This uprooting took place within the continuity of remaining enslaved. In this sense, the lives of many Loyalist slaves fit into David Brion Davis's "unconventional experiment in imagining, defining, and challenging certain boundaries related to the history of American slavery." "11 Loyalist slaves, while intertwined with the main currents of colonial American slavery, challenge historians to rethink the boundaries of bondage in the American colonies because of their migration to new areas of slavery outside of the national borders of the post-Revolutionary United States. 
By integrating the secondary literature on slavery in the late colonial and Revolutionary era with primary source documentation about Loyalist slaves (such as slave advertisements, Loyalist claims, organizational records, and other sources), this article attempts to highlight the complexity of their American background. The American Loyalists who came to the Maritimes brought between 1,200 and 2,000 slaves with them. ${ }^{12}$ These slaves shared the experience of American bondage, but their lives varied by gender, age, plantation size, master, labour requirements, and culture. Despite these variations, most Loyalist slaves had experienced the process of going from African to African American. Once in Maritime Canada, slaves who had experienced the culture and work patterns of South Carolina found themselves in the same towns as urban slaves from New York or Boston. These distinctive experiences collided and converged in the Maritimes and slowly refashioned slavery in the new Loyalist region. Before historians can begin to understand slavery in Maritime Canada, we must have a good idea of the cultures, customs, and labor expectations that slaves brought to the region from the United States.

This article serves as a prequel to my book, Blacks on the Border, about the experiences of African American migrants in Nova Scotia after the War of 1812. ${ }^{13}$ The research for that book convinced me that there were deep antecedents to black-white relations that had been formed in the eighteenth century. These relations, despite historians' emphasis on free blacks in Maritime Canada, occurred in the wider context of Anglo-American slavery that expanded after the Revolutionary War in the United States, but also interestingly in Canada. This expansion resulted in the United States becoming, as Adam Rothman demonstrates, a "Slave Country." Maritime Canada was not immune to this postRevolutionary expansion of black slavery. Instead of thinking of the Maritimes as a place where blacks found freedom, we need to understand it in more complex terms as a geographic space between 1750 and 1850 that encompassed both American slavery and limited freedom for people of African descent. The history of slavery in the Maritimes has yet to be told, but it is part of my overarching research project, which must begin with an understanding of the American origins of Loyalist slaves who were brought to Maritime Canada. Building on the work of other historians of Canadian slavery, this article hopes to be a small step in a much larger scholarly endeavor to understand slavery in His Majesty's loyal British North American colonies. ${ }^{15}$

\section{Types of Northern Slavery}

The complexity of northern slavery cannot be reduced to a single model, because there were differences between regions, within regions, and even by township and municipality. Yet, historians can highlight some of the major features and contours of Northern slavery. Between 1725 and 1775, historian Ira Berlin notes "the 
character of northern slavery changed." These changes occurred "unevenly" and had their greatest impact on coastal urban centres, fertile farming regions, and the Middle Colonies more so than New England. ${ }^{16}$ Slavery became more entrenched in the regional economy as importations from Africa increased steadily. This influx of Africans resulted in "higher mortality, lower fertility, stricter discipline, harder work, and other manifestations of the degradation of slave life that accompanied the open slave trade in the Chesapeake and the lowcountry."'17 By 1770, the black population in the Middle Colonies and New England reached about 50,000. In New England, Africans and African Americans accounted for only 2.5 percent of the population, while they comprised about 6.5 percent of the population in the Middle Colonies. In New York, slaves accounted for at least eleven percent of the population and possibly as much as fifteen percent. ${ }^{18}$ In nearby East Jersey, there was a "steady increase of the rural black population." 19 Slavery also grew in Pennsylvania and particularly in Philadelphia during the 1750s and 1760s before tailing off thereafter. The small percentage of blacks in the North masks the expansion of slaveholding in several urban areas and fertile farming regions such as Long Island, parts of Connecticut and Rhode Island, the Hudson River Valley and Pennsylvania. The changes to the black population resulted in new forms of work and slave life that partially defined the experience of many Loyalist slaves before they migrated to Maritime Canada. ${ }^{20}$

The expansion and extent of slavery differed between New England and the Middle Colonies. New England remained a society with slaves where wage labor was firmly entrenched. In contrast, the Middle Colonies became "increasingly committed to slavery." ${ }^{21}$ Yet, there were certain commonalities between both regions as slaves worked in a mixed economy and engaged in a wide variety of occupations. As Graham Russell Hodges notes, the work of rural slaves was not divided by sex because "black men and women laboured in the fields, cut firewood, and fed animals." ${ }^{\prime 2}$ Generally, northern slaves lived in close proximity (usually in the same house) to their masters along with perhaps one or two other black slaves. They also commonly worked alongside their masters as farmers, domestics, or urban artisans. ${ }^{23}$ Northern slaves, while retaining some aspects of "African culture," faced greater acculturation and creolization because of the sheer number of white people in their midst. They became more accustomed to closer contact with the dominant Anglo-American society than their brethren in the Chesapeake and certainly the Lowcountry. ${ }^{24}$

In urban areas throughout the North, slaveholding expanded beyond the elite to include members of the middle and artisan classes. Undoubtedly, some slaves were status symbols, but they also served more utilitarian functions. As several historians argue, one of the hallmarks of northern slavery was the use of African Americans in occupations including baking, butchering, carting, carpentry, shipbuilding, and seafaring. ${ }^{25}$ This marked a shift from working in households to the centre of "urban productivity" in artisan shops. ${ }^{26}$ The urban slaves of 
American Loyalists in the North followed this pattern. They worked quite often as domestic servants, but also provided essential labour that allowed the businesses of their owners to prosper.

Loyalist slaveholders included members of the middle and artisan classes. ${ }^{27}$ They represented an increasingly significant element among northern masters. As James Horton and Lois Horton note, "middle-class artisans and businessmen" in New York and to a lesser extent Boston and Philadelphia made important use of slaves. Nevertheless, the well-to-do were overrepresented in the ranks of slaveholders, but slave ownership still extended throughout several levels of society. The increasing number of masters from the middling ranks of society is reflected in the types of slaveholders who migrated to Maritime Canada. ${ }^{28}$

One of the best sources for the occupations of Loyalist slaveholders is the Minute Book of the Port Roseway Associates (PRA). The PRA was formed to assist selected Loyalists in establishing a new settlement in Nova Scotia. Although the PRA included Loyalists from various parts of colonial America, several were from urban centres in the northern colonies. With regards to occupation, the vast majority of these Loyalists were listed as merchants, merchant-tailors, bakers, carpenters, blacksmiths, mariners, and grocers. For example, Boston bookbinder Andrew Barclay evacuated to Nova Scotia with at least five "servants." ${ }^{29}$ New York City's Joseph Totten was a shipbuilder and merchant. He owned several slaves who perhaps doubled as both domestic servants and labourers in his business. ${ }^{30}$ Charles Oliver Bruff held several "servants" and worked as a silversmith. ${ }^{31}$ Boston tailor and merchant Patrick Wall owned three slaves ranging from five to twenty-one years of age. ${ }^{32}$ Twenty-six year old Bill and teenage Daniel were owned by cabinetmaker William Black in New York City. ${ }^{33}$ Valentine Nutter, a stationer and storeowner, brought at least two slaves from his New York home to Shelburne, Nova Scotia. ${ }^{34}$ A hatter by trade, Peter Lynch possibly owned four slaves in New York before evacuating to Nova Scotia. His slaves included males and females ranging in ages six to thirty-five. ${ }^{35}$ The variety of Loyalist occupations was reflected in the work of their slaves as they laboured as household servants, skilled and unskilled workers and farm hands.

Loyalist household slaves were expected to accomplish various domestic chores. Black women made up an important part of this workforce and their responsibilities included cleaning, washing, cooking, spinning, and weaving. ${ }^{36}$ The records of black slaves leaving New York for Maritime Canada are replete with Loyalists' owning one female slave from an urban area. In all likelihood, these women labored as domestics. ${ }^{37}$ As historian Leslie Harris states, black female slaves "aided white women (free and indentured) with cooking, cleaning, and childcare." However, female slaves of artisans also "assisted the men in their skilled tasks as necessary." 38 The work of domestic slaves, male and female, encompassed numerous tasks. Rhode Island master James MacSparran's slaves were responsible for "cutting, carting, threshing, and milling wheat and loading 
wheat straw into the barn; hilling, hoeing, gathering and husking corn and cutting cornstalks; mowing, raking, and carting hay; digging and sledding stones and building stone walls; building fences; cutting and scowing wood; hoeing and picking peas, beans and turnips; and mending baskets." ${ }^{39}$ Domestic slaves were invaluable contributors to the prosperity and stability of northern households.

The household chores that Loyalist slaves engaged in throughout the northern colonies would prove important to their masters in the mixed economy of Maritime Canada. Their versatility as slaves made them valuable assets during the Loyalist resettlement as they helped build homes, but also cooked, cleaned and took care of the children. In the New York Royal Gazette, Loyalists purchased and sold slaves who performed several important aspects of household labour. The diversity of household tasks that Loyalist slaves endured is underlined in the typical phrasing of advertisements, which highlighted that the male or female slave "understands all kinds of housework." 40 The types of work listed in the Royal Gazette included spinning, washing, cooking, ironing, and coachman. The advertisements painted slaves as being "good," "excellent," and "valuable" for the work they could do as cooks and washers. ${ }^{41}$ Of course, this has to be set in the context of owners attempting to make a profit, but the wording also speaks to the value placed on domestic servitude by some Loyalist slaveholders and the types of work that their slaves faced.

One Loyalist owner promised that his slave "is a good COOK and WASHER," while John Lynch noted that he wished to sell a "very valuable Negro Wench." ${ }^{42}$ She was considered valuable in New York City because she had been a good cook and reliable house servant. Another master reported that his slave was an "excellent cook," could handle twenty people at dinners, and was "the most careful and best coachman on the Continent." "43 William Wright promised that his teenage male slave had been brought up to "wait on a gentleman" and proved to be "very handy in a house." young children. One owner stated that he possessed a "Smart Negro Boy" who could serve small families. ${ }^{45}$ Loyalist merchant Henry Guest offered a nine yearold boy for sale who had "been used to attend on table." He further noted that the boy was "remarkable handy at any other work his strength is adequate to." ${ }^{40}$

Loyalist urban slaves also performed wide-ranging forms of labour outside of households. The occupations that these slaves learned were transferable to the major points of Loyalist settlement in Maritime Canada such as Saint John, Shelburne, Annapolis, and Halifax. Similar to Boston and New York, these urban centres used slave labour in the shipping and timber industries. Sometimes the chores of Loyalist slaves were thrown under the vague appellation of "labourer." For example, Major John Coffin's slaves, Paul and Harry, were listed only as "stout labourer[s]." ${ }^{47}$ The tasks that these two men might have performed were almost limitless. The variety of labour that Loyalist slaves did outside of households ranged from woodworking to maritime trades. As in New England, where "slaves 
became an important part of the shipbuilding work force," Loyalist slaves in New York also laboured in Maritime industries. ${ }^{48}$ In some cases, these occupations required skilled or semiskilled labour. For example, Caesar, the property of James Humphreys, worked as a sail maker. ${ }^{49}$ One Loyalist master noted that his slave was "a good carpenter and sawyer," while Sam Ivey's owner described his runaway property as "a carpenter and caulker by trade." $5^{0}$ Another advertiser in the Royal Gazette planned to sell a "Likely NEGRO MAN, about 28 years old, [who] is both a Carpenter and Cooper; [and] would be a valuable acquisition in the West-Indies or Nova-Scotia." ${ }^{\prime 51}$ But the majority of urban slaves did not work in occupations that required skills, but rather as James Horton and Lois Horton argue, "strong backs." ${ }^{52}$ For example, in 1782, Loyalist baker Richard Jenkins complained that two of his slaves had escaped. Caesar and a female slave were "well known" because they had "carried Bread" and biscuits "through the city." ${ }^{53}$ "One year later, Caesar escaped again and Jenkins placed another advertisement emphasizing that the slave "is well known by carrying bread and biskets about the streets." ${ }^{54}$

Loyalist slaves also provided important agricultural labour for the "breadbasket" of the North especially along the Hudson River and other areas. These black farmers did not usually work in gangs like their counterparts in the Chesapeake, but rather alongside a few other black slaves and white indentured servants. ${ }^{55}$ The fragmentary 1755 New York "Census of Slaves" demonstrates that African Americans were owned in relatively small numbers and worked in rural areas within white communities. ${ }^{56}$ Some northern slaves who lived in semirural areas such as Long Island represented a mobile and multifaceted workforce. ${ }^{57}$ They could be responsible for rural, urban and domestic responsibilities. For example, one Long Island slaveholder noted that his female slave performed town and country duties and could wash, iron and cook. ${ }^{58}$ This slave engaged in multioccupational work, but was also highly mobile with an understanding of city and country labour. In parts of the North, as the eighteenth century progressed, rural and semi-rural farmers came to increasingly rely on slave labour. But this emerging reliance on slave farm labour did not, as Berlin notes, result in the creation of large plantations with the exception of a few areas in New York, Rhode Island and Connecticut. ${ }^{59}$ Instead slave farmers "remained jacks-of-all-trades, engaging in all aspects of the northern agricultural regimen." ${ }^{\prime 00}$ The work of northern rural slaves was not sharply divided between "house, yard, and field." Rather, these tasks became "blurred" as slaves had to perform multiple tasks in various settings. ${ }^{61}$

Thanks to the pioneering work of Graham Russell Hodges, historians have an understanding of the basic contours of small farm slavery in the North. In the case of Monmouth County, New Jersey, during the first year of settlement, male slaves grew "Indian corn, oats, flax, and buckwheat." ${ }^{2}$ The duties of black male slaves included carting various fruits and vegetables; while also taking care of livestock. During each season, slaves had to perform numerous tasks including clearing land, planting, fixing fences, and harvesting. Female slaves also participat- 
ed in agricultural labor, but had the added burden of domestic servitude, which meant being on-call 24 hours every day for the master's family. No matter the season, as Hodges argues, "any enslaved black on a reasonably sized farm had to perform a vast array of chores efficiently and well." ${ }^{\prime 3}$ The value of Monmouth slaves is underlined by the fact that some local Loyalists carefully evacuated with their chattel after the Patriot takeover. For example, Captain Longstreet, a farmer from Freehold, took thirty year-old Betts and teenage Phillis to Annapolis, Nova Scotia. ${ }^{64}$ The enormous amount of work performed by black farm slaves in the North would be transferred by many of their owners to the farms of Maritime Canada.

Slave work learned on northern farms would be repeated as Loyalist masters attempted to turn the uncultivated land they were granted in the Maritimes into productive farms. The work patterns of rural or semi-rural Loyalist slaves reflected general trends of farming among northern slaves. For example, Frederick Williams had been a farmer in Frog's Neck, Westchester County. He owned a "Landed Estate," which included "13 oxen, 7 Cows, 8 young Cattle," and other livestock. In his Loyalist claim, Williams wrote that he lost several slaves to the "Rebels" including an adult male and female along with their "three or four children." These slaves were responsible for all sorts of farm chores, but also domestic service. ${ }^{65}$ John Polhemus owned 180 acres of land on Long Island. He owned a few slaves including twenty year-old Dinah and her infant. Dinah's responsibilities ranged from domestic service to yard and farm work. Carrying his ideas of black slavery to Annapolis County, Nova Scotia Polhemus obtained more slaves and held ten in bondage as late as 1807. ${ }^{66}$ Colonel Isaac Allen of Trenton, New Jersey, owned a small farm of 120 acres on the Delaware River, a "valuable piece of woodland" near Trenton of thirty-five acres, and other property. The land near the river included "a Farm House and Barn with Orchards." Allen possessed several "servants" who laboured in his house and small farms. ${ }^{67}$ In nearby Bergen County, John Francis Ryerson owned several tracts of land and "built two Houses." In his memorial to the Loyalist Claims Commission, Ryerson listed his losses, which included several items related to farming including five cows, thirtynine sheep, seventeen hogs, sixteen young horned cattle and substantial bushels of Indian corn, rye, and wheat. Ryerson also complained that he had lost "1 Negroe Man." ${ }^{\prime 68}$ But, Ryerson did not mention that he had evacuated his farms with a male, female, and child slave. These slaves would have been responsible for the planting, growing, harvesting, land clearing and production processes on Ryerson's farm. Their experience of northern slave farming mirrored that of slaves in Monmouth County ${ }^{69}$ In Westchester, wealthy Loyalist sheriff James DeLancey possessed immense tracts of land, which included farms and mills. Before the outbreak of the war, DeLancey had been "improving and working upon the farm." ${ }^{\prime 0}$ Certainly part of the improvements to his farm came from the labour of several slaves he had inherited from his father. DeLancey brought six slaves to 
Nova Scotia where they continued to work both as farm labourers and domestic servants. ${ }^{71}$ These slaves' familiarity with the northern agricultural regimen prepared them for the difficult task of farming in Annapolis County, Nova Scotia.

The work of Loyalist farm slaves included several tasks that left little time for leisure. As Hodges points out, "the ceaseless demands of agriculture's seasons belie any notion that northern farmers lacked sufficient work to make slave ownership profitable." 72 As stated earlier, Loyalist slaves were multi-occupational, versatile, and responsible for both town and country labour. The variety of work performed by rural or semi-rural Loyalist slaves is preserved in the New York Royal Gazette. In 1780, one owner described his female slave as "bred up in the country" and prepared to perform the type of work that would be expected of a semirural slave; while another slave woman from Long Island was "fit for the country." 73 The heavy expectations placed on rural female slaves were outlined in one slave advertisement, which promised a woman who was "acquainted with all country work, spinning, sewing, and Dairy." This woman's owner also described her as "exceeding [sic] good" at housework and with children. ${ }^{74}$ The various tasks of Loyalist farm slaves from tending livestock to cleaning out horse stables would make them the most useful slaves in Maritime Canada as they could perform the tasks that accompanied building homes, clearing land, and preparing for harvest. Rural and semi-rural northern slaves would experience the most continuity between their old and new homes, as farm work and domestic work learned on the small to mid-sized farms of New England and the Middle Colonies would be continued in the Maritimes.

Northern Loyalist slaves emerged from unique cultures and living conditions that informed their experience as much as the labour they performed. Despite the large number of whites in the North, cultural adaptation and retention of African cultural norms competed and converged in the world of northern slavery. In some ways, Black Yankee slaves adopted aspects of Anglo-American culture such as religion, names, and holidays, but also strongly retained African customs or integrated them into European cultural traditions. These slave cultures revolved around the smallholdings, or so-called "family slavery," that defined the institution in the North. The majority of slaves lived, laboured, slept, and socialized with only two or three other slaves in white households and neighborhoods. ${ }^{75}$ This close proximity resulted in quicker acculturation for northern Loyalist slaves than their counterparts from the South Carolina and Georgia Lowcountry. The vast numerical superiority of whites resulted in many Afro-Yankees having close contact and significant interaction with Anglo-American society. Yet, the general pattern of close contact varied and some northern slaveholders attempted to erect barriers between African American slaves and white families by maintaining "Negro Kitchens" or "Negro Rooms," which some Loyalists such as Jonathan Odell also did in the Maritimes after the war. ${ }^{76}$ Moreover, as Hodges and other historians point out, close proximity did not necessarily lessen the coercive nature of 
master/slave relations. ${ }^{77}$

During the eighteenth century the general contours of northern slavery changed as a result of an influx of involuntary migrants from Africa and the West Indies. This migration altered patterns of acculturation, while strengthening and reintroducing cultural bonds with Africa. As a result, Loyalist slaves in the North became a diversified, multicultural, multiethnic, and multiraial group, but remained influenced by the patterns of family slavery that had come to dominate northern slavery from the early eighteenth century.

Between 1740 and 1770, the northern colonies experienced an influx of Africans and seasoned Africans from the West Indies. This migration partially changed the culture of northern slaves. In major port cities, such as Philadelphia and New York, Africans arrived in increasing numbers. Northern slaveholders needed black labor for burgeoning farms and the booming artisan shops of urban centers. $^{78}$ In the case of Loyalist slaves, the migration of Africans built on the multiethnic population of slaves in the North. Slave advertisements and Loyalist shipping records reveal the diversity of African and African descended people that made up the northern slave population. Other northern Loyalist slaves came from the West Indies or other parts of the colonies after the evacuation of southern Loyalist strongholds in Savannah and Charleston.

In 1779, York arrived in New York from Jamaica and his owner used him as a chimneysweeper. ${ }^{79}$ Another fifteen-year-old slave named Cain only spoke "tolerable" English and had recently arrived from Charleston during the summer of 1780. ${ }^{80}$ Mr. Dole complained that his slave, Jenny, a "native of Georgia" had escaped from him. Only a young teenager, Dole feared that Jenny would attempt to board a vessel, as she "is a remarkable thief and liar." "81 Gideon White complained that his "Negro Boy" named Pero had runaway. He described the fifteen year-old as "part Spanish Indian" and feared the runaway would leave Boston on a vessel. ${ }^{82}$ Another Loyalist runaway had been born in Jamaica and arrived in New York after leaving Charleston. Her owner noted that she had three cuts on each cheek, which indicates that she had been born in Africa. ${ }^{83}$ In 1778, Jonathan Eilbeck described his slave Myrtilla as an African native who had previously lived in Bermuda. ${ }^{84}$ Five years later, Loyalist slaveholder Valentine Nutter offered five guineas for his escaped slave Jack. Nutter noted that Jack spoke "very little English to be understood." ${ }^{55}$ William Rhinelander's slave could only speak "broken English," which suggests that like Jack, Rhinelander's slave might have been born in Africa. ${ }^{86}$ New Yorker Jonathan Fowler described his runaway slave as speaking "much like a Guinea Negro." ${ }^{\text {87 }}$ Cato had been purchased in New York "out of a Guinea Ship" in 1763 when he was only seven years old. In 1783 his owner, John Bridgewater, transported him to Nova Scotia. ${ }^{88}$ The multicultural character of northern slaves created a fragmented type of slavery that was exacerbated by the chaos of war. Loyalist strongholds such as New York City became the home to various types of American slaves who would take their complex his- 
tories and backgrounds to Maritime Canada.

Although the black slave population in the North had consistent and constant contact with Anglo-American cultural norms, the influx of Africans created opportunities for Northern black slaves to reject aspects of Christianity and celebrate more African centred cultural norms. These aspects of African culture included burial ceremonies, housing, folklore, singing, and dancing. ${ }^{89}$ Some of these traditions accompanied northern Loyalist slaves to Maritime Canada, such as "Negro Frolicks." These "Frolicks" were banned in Shelburne, Nova Scotia in 1785 because they were viewed as a source of annoyance, but also as seedbeds of black insurrection as both free and slave participated. ${ }^{90}$ The partial "Africanization" of the northern slave population changed sex ratios, slave mortality rates, family structure, and reduced the free black population's numbers. The influx also resulted in the rejection of Christianity by some slaves and the emergence of African cultural activities such as Negro Election Day and the Pinkster Festival. ${ }^{91}$ As Berlin argues, this:

$[\mathrm{N}]$ ew African influence was manifested most fully in the emergence of a variety of festivals-Negro Election Day in New England and Pinkster Day in New York and New Jersey. These celebrations featured fetes of ritual role reversals of the sort that were common throughout Africa and Europe, and their emergence in the northern colonies during the middle years of the eighteenth century doubtless owed much to their dual heritage. ${ }^{92}$

This dual heritage of some northern slaves can be examined through the names of Loyalist slaves who migrated to Maritime Canada. Generally naming patterns fell into three categories: Anglicized, African, and classical. As Leslie Harris argues, the use of African names could sharply draw "cultural distinctions between Europeans and Africans and helped justify enslavement." ${ }^{\prime 3}$ Loyalist slave advertisements and other documents are littered with classical names, which could be seen as a way to belittle slaves. ${ }^{94}$ Mechal Sobel's description of classical names is instructive:

The third distinct group was that of demeaning classical names: Cesar, Hercules, Baccus, and Hannibal all appear on the slave property lists. When Thomas Jones's house was served by Venus, Pallas, Daphne, and Mercury, all black slaves, it is clear he chose the names and it is likely he recognized both the irony and the degradation involved. He was participating in a very old tradition, wherein classical names had early become a humiliating badge of servility. ${ }^{95}$

Some Loyalist slaves played an active role in renaming themselves. For example, James Humphreys complained that his slave Caesar had runaway and could be "lurking in New York City." A valuable skilled slave, Humphreys noted that his slave called himself "Julius Caesar." Although some Loyalist slaves had African names, the extant documentation clearly shows that Anglicized names were com- 
mon and surnames were not the preserve of free blacks or eventual Black Loyalists such as Boston King. Common male names of northern Loyalist slaves were Sam, Jack, Dick, and Joe; while female names found in documentation included Hannah, Dinah, Mary, and Priscilla. ${ }^{97}$ Of course these names were also common among whites and perhaps this shows a level of assimilation and acculturation among slaves as African names were slowly replaced with Anglo-American names. Some Loyalist slaves simply took the last name of their owner, while others kept the surnames of previous masters. For example, Robert Gibbs's young slave was named Frank Gibbs, while Joseph Skinner was the property of Mr. Lynch. ${ }^{98}$ However, sometimes Anglicized names simply replaced African names. As Leslie Harris points out, some owners transformed Quaco to Jack.99 The names of slaves could vary greatly within the household of one slave owner. For example, Poughkeepsie Loyalist John Beardsley's three slaves were named Scipio, Peter Beardsley, and Dinah. ${ }^{100}$

Northern Loyalist slaves encountered several difficulties in attempting to maintain family life. ${ }^{101}$ As Melish notes in the case of New England, "virtually every slave was a member of two families simultaneously, both conditioned by slavery." 102 These two families, one white and the other black, forced African American chattel to negotiate the contours of familial relationships between their masters' kin and their own husbands, wives, and children. As historian William Pierson notes, "Northern slave owners rarely held enough bondsmen to permit the expense of separate living quarters for the races, common residence during the more domestic hours reinforced the proximity of workday relationships." ${ }^{{ }^{103}}$ However, close living and working conditions did not necessarily mitigate some of the harsh aspects of American slavery. Yet, it did create conditions whereby northern slaves had closer contact with their masters than slaves from the southern colonies. Northern Loyalist slaves were conscious of the notion of belonging to a white "family." For example, a "sickly" slave named Dinah on her way from New York to Nova Scotia commented that she had "always been in the family" of her owner. ${ }^{104}$ Perhaps Dinah's own words reflected an expectation that her master should provide for her medical care after years of service. New Jersey slaveholder John Barbarie's slave Plato was described as having been "Born in the Captain's Family." 105

Northern slaves faced three major obstacles to the creation, development and maintenance of families. First, most slaves resided in households with only one or two other slaves and the attempt to find a marriage partner could involve traveling great distances. In most cases Loyalist slaves did not number more than three per household. Some masters possessed one or two young slaves whose biological parents did not reside in the same household. For example, Westchester farmer Samuel Davenport took two young slave children to Shelburne, Nova Scotia. His chattel, Bet and Nan, were only five and seven respectively. John Jakeways also migrated to Shelburne with one "fine boy" named Simon. There is 
no mention of Simon's parents in the extant documentation. Second, Northern slaveholders discouraged their property from marrying and having children. Not surprisingly, as Berlin argues, masters "routinely separated husbands from wives and parents from children, and only reluctantly extended visitation rights." 106 Lastly, the influx of slaves from Africa and other places were disproportionately male. Although it is rare to find documentation of an entire nuclear family intact, there are examples of mothers residing in the same household as their children. For example, Sarah and her infant daughter Susannah both lived with their owner James Bogart and accompanied him to Shelburne. These three problems along with the chaos of migration made the maintenance of Loyalist slave families difficult, but not impossible.

The obstacles in the formation of Loyalist slave families leads to important questions and comments about women's slave experience. Without question, slaveholders coerced sexual labour from their female slaves and this resulted in the labour of reproduction. These difficulties impacted black and white families as well as the lives of enslaved men and children. As the work of Jennifer Morgan shows, slave women were valued for their physical and reproductive labour. ${ }^{107}$ It seems that in the case of female Loyalist slaves, the archive represses information about rape, prostitution and paternity, but there are a few examples of slaveholders owning one slave woman and a very young child. For example, James Bogart left New York City for Shelburne accompanied by twenty year old Sarah and an infant. Did Bogart father the child? Did he engage in a coercive relationship with Sarah? This is not clear. The presence of mulatto or light skinned slaves in Loyalist records is also an indication of the labour of reproduction that female slaves endured. An example of this is William Wilson and two teenage girls from Virginia. According to the recorder, Wilson obtained the two slaves as part of a marriage settlement. Strikingly, these slaves, Betsey and Jenny, were described as "3/4 white."108 Did Wilson father these slaves? What role did sexual coercion play in his relationship with their parents? Whatever the case, when "black girls worked and lived in close proximity to white masters, the result was frequently (an) exploitative sexual relationship." 109

\section{Southern Slaveries}

Chesapeake and Lowcountry slaves endured vastly different systems of American bondage, which can partially be attributed to geography. However, within these disparate forms of southern bondage, slaves encountered diverse labour systems that overlapped and occurred in each region. There were several sub-regional variations of southern bondage that produced various types of Loyalist slaves in Maritime Canada. Some of these African Americans came from the staple producing parts of the Chesapeake and Lowcountry, while others worked in more diversified economic areas such as the South Carolina backcountry. Still others 
laboured as urban slaves in Norfolk or Charleston. Loyalist slaves from the staple-producing areas of the Chesapeake and Lowcountry arguably faced the most difficult adjustment to the rigors of continued enslavement in Maritime Canada. They went from living among visible and substantial black populations to a region with mostly sparse and scattered black communities. Moreover, the growing of tobacco or rice gave them little experience for the types of slavery they found in Nova Scotia and New Brunswick. In contrast, slaves who worked in the mixed agricultural economy of places such as Somerset County, Maryland or in urban areas would have been prepared for the type of slavery they encountered in Maritime Canada. These slaves' work patterns would be repeated in New Brunswick and Nova Scotia on rural farms and urban centers, which required experienced farm slaves and urban workers familiar with a mixed economy. Whatever the background of southern Loyalist slaves, both masters and slaves had to readjust their understandings of slavery in the challenging environment of postwar resettlement. After 1783, Loyalist slaves from various regions of southern slavery were thrown into a type of bondage that resembled the institution in New England and parts of New York.

Similar to the northern colonies, slavery in the Chesapeake and Lowcountry underwent major changes during the eighteenth century. These distinct southern regions became slave societies with black populations that dwarfed the numbers of slaves in the Middle Colonies and New England. ${ }^{110}$ Slavery flourished in the tidewater Chesapeake and the Lowcountry, but it also crept into the more inland regions of both colonies. In South Carolina, the number of Lowcountry slaves dwarfed that of the inland regions, but as Rachel Klein notes slavery expanded and became more important throughout the middle and backcountry. ${ }^{111}$ The increasing importance and commitment to slavery in these regions is illustrated by the drastic increase in the slave populations during the eighteenth century. For example, the number of slaves in South Carolina increased from 2,400 in 1700 to 94,000 in 1780, while Virginia's also increased from 13,000 in 1700 to 224,000 eighty years later. The similar growth in both colonies masks the distinct and different reasons for the slave population's increase. In the Chesapeake, slaveholders imported Africans in large numbers between 1720 and 1750 (over 12,000 each decade), while it tailed off afterwards until the 1780s when allegedly no Africans were imported. In South Carolina, the African influx started off slower, but between 1750 and 1780, over 16,000 Africans came in each decade. ${ }^{112}$ The slave population in the Chesapeake also grew because they were a "prolifick" people with a high rate of natural increase. ${ }^{13}$ As planters imported more women to correct the sexual imbalance and the size of plantations and the numbers of slaves per household increased, the black population became selfreproducing by the middle of the eighteenth century. In contrast, the Lowcountry's reliance on imported Africans and the high levels of infant mortality due to the horrible conditions of rice planting resulted in the population not 
becoming self-reproducing until well after Chesapeake slaves. In many ways, according to Berlin, the "transformation of slavery in the lowcountry followed the pattern established in the Chesapeake colonies-increased demand for slaves, direct African importation, and a general degradation of slave life-but surpassed it in all respects." 114

The changes to slavery in both regions were based on the production of staple export crops such as tobacco in the Chesapeake and rice and indigo in the Lowcountry. Chesapeake slaves usually laboured under their white owners or overseers and natural reproduction and the cultural movement from African to Creole eventually created a unified African American society, while Lowcountry slaves enjoyed a black majority. Lowcountry slaves laboured in an extremely unhealthy environment, while Chesapeake slaves did not face the same type of danger from tobacco production. However, the massive influx of Africans left black society in the Lower South somewhat fragmented in terms of ethnicity and geography. Moreover, unlike their counterparts in the Chesapeake who experienced some contact with Anglo-American cultural norms, Lowcountry slaves "remained physically separated and psychologically estranged from the EuropeanAmerican world." "115 Within the overarching structures of rice and tobacco cultivation, other forms of work such as the production of wheat and grain along with forms of urban servitude meant that slaves also performed a variety of tasks. As Jean Elliot Russo notes, "On Maryland's lower Eastern Shore, for example, a diversity of activities and the flexible use of enslaved labor characterized the local economy from the earliest period of settlement. In this region, a slave-based labor system evolved in a diversified economy." "116 Loyalist slaveholders came from these various types of southern slaveries and their understandings of black labour would be transferred to Maritime Canada after 1783.

Loyalist slave owners from the Chesapeake and Lower South brought more slaves per household to the Maritimes at the conclusion of the Revolutionary War than those from New England and the Middle Colonies. Prior to the Anglo-American conflict, they also held more slaves per household than most northern masters. Nathaniel Bullern, a physician from Charleston, brought at least ten slaves to Nova Scotia, while a fellow South Carolinian James Edward Boisseau lost fourteen slaves to the rebels, but still brought five "servants" to the Maritimes who had no surnames. ${ }^{117}$ Although these men were not large-scale slaveholders by southern standards, they were in the upper echelon of owners who went to Maritime Canada. Large-scale Loyalist slaveholders such as Elias Ball did not migrate to the Maritimes, usually choosing instead to live in the British West Indies or England.

Loyalist southern masters can be divided into two major categories of slaveholders: owners with at least eight slaves and those with less than eight. The first category consisted of large-scale slaveholders (by the standards of those who migrated to Maritime Canada, which means that they held at least eight slaves prior 
to the Revolution) who were not representative of Loyalist southern slaveholders who migrated to the Maritimes. The other group of masters accounted for the majority of southern owners who went to the Maritimes. Generally speaking, they were landowners with some slaves who worked in mixed agricultural production. These slaveholders usually traveled to the Maritimes with very few slaves usually under five and more likely two or three. Urban Loyalist slaveholders fell into both categories with the majority owning less than five. ${ }^{118}$

The records of Loyalist slaveholders who owned more than eight slaves (and eventually migrated to Maritime Canada) and the types of plantations they operated can be found in the records of the Loyalist Claims Commission. Generally, these masters operated diversified farms, which sometimes produced one staple crop such as Indigo, but also generated income through the production of mixed agricultural goods. James Edward Boisseau owned one 3,000 acre plantation at Fair Forest Swamp of which about 150 acres were "under cultivation." He also possessed another three hundred acres of land at the Santee River Swamp. According to one supporting witness, it "was very good Land as good as any in Carolina." Boisseau's claim demonstrates that he relied on his slaves to produce "2000 Bushels of Corn," "1800 pounds" of indigo, and other assorted goods. They also oversaw Boisseau's livestock, which included cattle. Boisseau possessed about " 20 Negroes" according to one of his neighbors and claimed to have lost fourteen in consequence of his loyalty to the Crown. ${ }^{119}$ Captain John Saunders "resided on his plantation in Princess Anne County [Virginia]" at the outset of the rebellion. Saunders owned 800 acres near the Lynhaven River, which consisted of a "valuable" house and "an overseer's house." Saunders plantation produced various types of fruit, timber, oats, wheat, and Indian corn. Saunders lost ten male and two female slaves. ${ }^{120}$ His plantation is an example of the transition in the Chesapeake during the late eighteenth century away from tobacco to more mixed agricultural production. As Berlin notes, by "the eve of the American Revolution, the value of cereal production exceeded that of tobacco in many parts of the region." ${ }^{21}$ A native of North Carolina, Captain John Legett spent his youth working as a carpenter, but four years before the Revolutionary War local records described him as a "planter." 122 He owned over 2,000 acres of land on Rockfish and Downing creeks and Cape Fear River. In his Loyalist claim, Legett wrote that he owned " a good sawmill," "a Black Smith's Shop," and "a Mill." Legett complained that he lost "9 Negroes, one a Black Smith" during the war. ${ }^{123}$ Despite these losses, he brought some slaves to Nova Scotia after the war. ${ }^{124}$

The majority of southern Loyalist slaveholders who migrated to the Maritimes did not own many slaves. These masters worked and lived in relatively close proximity to their slaves. Some of these owners came from coastal areas such as Norfolk, Savannah, and Charleston, but a significant group came from the South Carolina backcountry, in particular District Ninety-Six. ${ }^{125}$ These owners usually possessed smaller farms and like their urban counterparts, they possessed 
multi-occupational slaves. Interestingly, although these owners were from areas very different than the Maritimes in terms of climate and other factors, relatively close proximity of owners and slaves, the production of mixed agricultural goods and forms of town slavery would be partially replicated in Nova Scotia and New Brunswick after 1783. There are several examples of small-scale slaveholding among southern Loyalists in urban and more rural settings. James Alexander worked as a music teacher and owned "a House and Lot" in Savannah. He also possessed two slaves named Charles and Sue who were in their mid-twenties. ${ }^{126}$ John Hamilton owned a 350 acre plantation at Ninety-Six and lost four slaves during the war. His farm produced "Wheat, Rye, Oats, Flax," and Indian corn. ${ }^{127}$ Like other southern Loyalists slaveholders who migrated to the Maritimes, his slaves worked in a diversified economy and were responsible for numerous tasks associated with farming. Margaret Evans and her late husband owned small farms totaling 100 acres in North Carolina. They had some livestock and Evans claimed that they lost "200 Bushels of Corn" and "100 Bushels of Pease" to the rebels. The Evans family owned "5 Negroes," who like other southern Loyalist slaves labored in a mixed agricultural economy. ${ }^{128}$

Southern Loyalist slaveholders who migrated to Maritime Canada were diverse. They included men and women, old and young, urban and rural, wealthy and middling classes, and they used their slaves in a variety of functions. The occupations of their slaves ranged from urban domestic work to indigo production. These vastly different sets of occupational skills resulted in southern Loyalist slaves having variegated work experiences, which cannot be understood by simply examining their geographic origins.

Historian Donald Wright suggests that if "one thing dominated the daily lives of African Americans in colonial America, it was work." 129 The daily toil of black slaves in the southern colonies depended greatly on the type of crops grown in a specific region. Within each region several factors including plantation size, owner, and other variables make it difficult to generalize about the work patterns of southern slaves who endured forced migrations to Nova Scotia and New Brunswick after the Revolutionary War. However, it is possible to offer a preliminary outline of the types of labour that some Southern Loyalist slaves encountered. Generally, they worked in two different contexts that sometimes overlapped with one another. First, some engaged in the production of major staple crops such as tobacco, rice, and indigo. Second, other Loyalist slaves worked in mixed agricultural production.

The production of tobacco, rice and indigo each had different seasonal requirements and specific labour regiments. Tobacco cultivation required slaves to spend the first three months of a year clearing lands and sowing seeds. Between April and July, slaves "first prepared the fields" for the tobacco plants, and spent the rest of the spring and early summer months " $[\mathrm{t}]$ ransplanting, weeding, and replanting." "130 In August and September, slaves harvested the tobacco and even- 
tually cured and packed it. Slaves in the tobacco producing areas of the Chesapeake generally worked in the gang system under close supervision from an owner and sometimes an overseer. This system left little room for individual incentive to finish work quickly and as a result, most slaves worked slower and steadier than their counterparts in the rice growing Lowcountry. ${ }^{131}$

The Lowcountry had two staple crops: rice and indigo. Rice remained the more important of the two crops during the eighteenth century, but indigo, like wheat, in the Chesapeake provided an important secondary crop. As Morgan notes, the cultivation of rice "was the most arduous, the most unhealthy, and the most prolonged of all mainland plantation staples." 132 Although generally these slaves laboured under the task system, which encouraged slaves to finish their work so that they could spend the rest of the day as they pleased, the production of rice could be unrelenting and backbreaking. At the beginning of the year, slaves might be required to cut down trees and clear land, while they spent March getting fields ready for planting. The actual planting of rice could extend from April to June, which included seeding, "leveling ground," and cleaning out ditches. ${ }^{133}$ Slaves spent some of the summer months until early August hoeing the fields. In contrast to the Chesapeake where the labour remained steady during the tobacco growing season, Lowcountry rice slaves enjoyed some "relief" in August and early September. ${ }^{134}$ By the middle of September, slaves were finally able to harvest the rice. In contrast to rice, indigo had a shorter growing season. However, it required arduous work between April and August when slaves had to hoe and deal with insects. In the fall, slaves processed indigo by "stirring and beating as it fermented in vats." ${ }^{135}$ This type of work would have offered Loyalist slaves little preparation for the type of slavery they faced in Maritime Canada. The schedule and work of tobacco, rice, or indigo slaves would be very different from the growing seasons and agricultural produce of Nova Scotia and New Brunswick. ${ }^{136}$

Southern slaves who worked in mixed agricultural production experienced the most continuity in terms of the labour they performed in Maritime Canada. Moreover, slaves on these types of plantations and farms also held a variety of skills, which made them valuable assets in Nova Scotia and New Brunswick. For the most part, these slaves produced a number of different crops including some secondary staples, but also performed various types of household chores such as spinning, cooking, cleaning, and washing. For example, on his plantation in Princess Anne County, Virginia, Jacob Ellegood's slaves produced "300 Barrells [sic] of Corn," "250 Bushels of wheat," "1000 bushels of oats," and oversaw his livestock. In his claim for compensation to the British government, Ellegood complained that he had lost four slaves including two children. The slaves he lost were not described as field hands, but rather as "a very valuable" tradesman and a valuable "sawyer." One of the supporting witnesses for Ellegood's claim noted that his "Negroes [were] employed in the cutting of the timber." 137 Joseph Robinson of South Carolina complained that he had lost a "Negroe Wench very 
Valuable and a child." ${ }^{\prime 38}$ John Hamilton owned a few hundred acres at Ninety-Six, which included "30 Acres cultivated and enclosed." His plantation included different types of livestock and his slaves helped to produce Indian corn, wheat, rye, oats, flax and cotton. Hamilton stated that one slave he lost named Jack was an "excellent farmer" and one of his female slaves had been "an exceeding good House Wench." ${ }^{139}$ Virginian Stair Agnew claimed to have lost several slaves. His description of these slaves shows a diverse and skilled set of slaves. He expected to inherit "a very valuable cooper, plantation captain," a "sawyer," "an excellent House keeper," "a very good spinstress" and several younger slaves. ${ }^{140}$ The work patterns of Loyalist southern slaves sometimes prepared them for the various forms of slavery they encountered in Maritime Canada if they worked in urban areas or mixed agricultural farms, but those from primarily tobacco or rice producing plantations faced dramatic changes not only in terms of labour, but also in the types of culture they experienced in the Chesapeake and Lowcountry.

The culture of Loyalist southern slaves depended on several factors including demography, plantation size, family, levels of acculturation, proximity to the white population and African immigration. Although it is true that Loyalist slaves from the Chesapeake had more contact with the main currents of AngloAmerican society than their counterparts in the Lowcountry, in urban areas such as Charleston black slaves encountered whites quite often. As Wright notes in the case of Virginia, "even the wealthiest masters spent hours each day with their slaves, directing, working, punishing, cajoling, teasing, arguing, relaxing, laughing, and worshipping." ${ }^{141}$ But, this interaction should not be understood to mean that slaves did not maintain separate activities, ideas and festivities away from the eyes of their owners or the general white population in the Chesapeake. In contrast, most Loyalist slaves who lived in the Lowcountry often lived, ate, slept and socialized with other blacks. Loyalist southern slaves emerged from diverse and complicated cultures that were far removed from the realities of slavery that they found in Maritime Canada after the Revolutionary War.

During the eighteenth century, the black population in the Chesapeake grew because of two interrelated developments: an influx of Africans in the first part of the century followed by natural production as the slave trade tailed off in the Chesapeake toward the end of the century. ${ }^{142}$ In the Lowcountry, slave life was greatly influenced by two factors: a black majority in terms of population and an increasing influx of Africans throughout the eighteenth century. The black population and the isolation of some Lowcountry plantations allowed slaves to develop a distinct culture and language that remained far from the main currents of Anglo-American society. The slave population in the Chesapeake did not become a majority as it did in the Lowcountry, but the significant influx of Africans had an important impact on the cultural development of blacks in the region. These Africans came from a variety of places including the Bight of Biafra, Senegambia, and Angola. The results of African immigration were "imbalanced sex ratios, low 
fertility, high mortality."143 These diverse peoples found themselves in a slave society on the make. As plantation sizes and slaves per household increased and the black population in the Chesapeake began to achieve "rough sexual parity" in the Tidewater region a new culture emerged. ${ }^{144}$ By the 1740 s, native born blacks outnumbered Africans and they "mastered the terrain, perfected their English, and incorporated the icons and institutions of their owners' culture into their African inheritance. ${ }^{145}$ In the Lowcountry, several types of black culture developed in various areas ranging from urban centers such as Charleston to larger plantations. In cities, slaves had much more contact with local whites, while those on plantations rarely encountered large numbers of whites.

By 1750 , Chesapeake slaves started to live on larger farms and plantations and this allowed for the creation of families, kinship networks, and communities. The formation of slave families was made possible by the importation of more African females and the encouragement of masters who realized that slave husbands and wives promised to increase stability on plantations. Slaves were much less likely to runaway or resist if they lived with family members because resistance might result in sale to another owner. Part of the development of black families in the Chesapeake rested on the mixture of Africans and African Americans, which allowed for the development of black culture in the region. Also, the introduction and acceptance of some form of Christianity during the first Great Awakening also remained an important part of the acculturation process. ${ }^{146}$ As Berlin notes:

Slaves with teeth filed, hair plaited, or skin scarred in the ritual manner disap-
peared from the countryside. Some African words, gestures, and forms contin-
ued to shape speech, but no distinctive language emerged, and parents rarely gave
African names to their children. The pottery they made, the pipes they smoked,
and perhaps most importantly the way they celebrated rites of passage-partic-
ularly at birth and death-incorporated ancestral Africa into everyday African-
American life so thoroughly as to become almost invisible. African American
culture in the Chesapeake evolved parallel with Anglo-American culture and with
a considerable measure of congruence. ${ }^{1.7}$

The records of Chesapeake Loyalist slaves and their family structure are incomplete, but it is possible to make a few observations. First, they had much greater opportunities to form families and small plantation based communities than their brethren in the Middle Colonies and New England. Sometimes the size and holdings of individual masters indicates the opportunities for family creation and development. For example, John Herbert owned several hundred acres in Virginia. Although hardly a wealthy planter, Herbert still owned several slaves, which he brought to the Maritimes. The exact nature of the family structure among these slaves is not clear, but the ages of the slaves do indicate some form of familial or kinship network. His oldest slaves, Charles and Rose, were fifty and 
forty-five respectively. London and Hanna were thirty and forty years old at the end of the war. Herbert's other four slaves ranged in ages five to sixteen. ${ }^{148}$ Similarly, Nathaniel Bullern's slaves also indicate several different possibilities of family connections and kinship networks. His oldest slaves, Achabee and Catharina, were both sixty at the end of the Revolutionary War. Jenny and Prince were forty and thirty respectively. Bullern also owned another male slave in his early thirties and three females ranging in ages nineteen to twenty-five. His two youngest slaves were an infant named Sarah and a six year old. It is unclear who the parents of these children were, but it is possible that their parents were among Bullern's chattel. This type of slaveholding reflected the possibilities for Chesapeake and Lowcountry slaves to form families and certainly kinship networks. Marylander Caleb Jones had several of his slaves seized by the local government after he evacuated to New York and eventually New Brunswick. Although he would later return to Maryland and retain some of his slaves, his confiscated property included " 2 male slaves, 2 female [ditto], 3 male children +2 female [ditto]."'149

Despite the opportunities afforded Chesapeake and Lowcountry slaves for family formation, the end of the war resulted in some families being separated or child slaves being taken to the Maritimes without their parents. For example, James Dunn owned at least four slaves in Norfolk before the outbreak of hostilities. Escaping the onslaught of the rebels, Dunn and his slaves migrated to the Loyalist stronghold of New York City. In 1783, as the last Loyalists were evacuated, Dunn lost three slaves. According to his Loyalist claim, "One, Lucy, staid in the Fleet when Claimant went on Shore, but afterwards going on Shore was taken by a Rebel Colonel.'150 According to shipping records, James Dunn migrated to Nova Scotia with eleven year old Ben who "[w]as born \& brought up in the family of James Dunn." ${ }^{151}$ The complex culture of Chesapeake slavery differed substantially from what Loyalist slaves encountered in Maritime Canada after the Revolutionary War. In the Chesapeake, slaves had greater opportunities for family formation because of the increasing sizes of plantations and the encouragement of conjugal relations by some masters.

Loyalist slaves emerged from various contexts of American bondage. Once in the Maritimes, they and their owners had to adjust to a new climate, soil, and environment that refashioned understandings between masters and slaves. Loyalist slaves drew on their traditions of survival, work, and culture to ease the adjustment to Nova Scotia, New Brunswick, Cape Breton, and Prince Edward Island. Slaves from larger plantations within staple producing regions such as Lowcountry South Carolina probably endured the most shocking changes to their understandings of work and culture, while urban and semi-rural northern slaves experienced the most continuity between their old and new homes as farm and domestic work learned on the small to mid-sized farms of New England and the Middle Colonies would be continued in the Maritimes. 


\section{NOTES}

1 Some of the more recent literature on the Loyalists includes, Joseph S. Tiedemann, Eugene R. Fingerhut, and Robert W. Venables, eds., The Other Loyalists : Ordinary People, Royalism, and the Revolution in the Middle Colonies, 1763-1787 (Albany: SUNY Press, 2009); Maya Jasanoff, "The Other Side of Revolution: Loyalists in the British Empire," William and Mary Quarterly 65 (April 2008): 205-32; Jim Piecuch, Three Peoples, One King: Loyalists, Indians, and Slaves in the Revolutionary South, 1775-1782 (Columbia: University of South Carolina Press, 2008); Harvey Amani Whitfield, "Black Loyalists and Black Slaves in Maritime Canada," History Compass 5 (October 2007): 1980-1997; Alan Taylor, "The Late Loyalists: Northern Reflections of the Early American Republic," Journal of the Early Republic 27 (Spring 2007): 1-34. I would like to thank Stephen Hausmann, my colleagues at the Loyalist conference at the University of Maine in June 2009 and the anonymous peer-reviewers.

2 Book of Negroes, Guy Carleton Papers, RG 1, Nova Scotia Archives and Records Management (hereafter NSARM).

3 Minute Book of Port Roseway Associates, Volume 1, 1782, MG 9, B 9-14, NSARM.

4 Nova Scotia Packet and General Advertiser (Shelburne), 3 August 1786.

5 John Herbert, Loyalist Claims Commission, AO12/55/18, AO12/109/170, NSARM.

6 Book of Negroes, Guy Carleton Papers, RG 1, NSARM.

7 Book of Negroes, Guy Carleton Papers, RG 1, NSARM; Reuben Chase, Loyalist Claims Commission, AO12/25/159, AO12/109/112.

8 The American Revolution provided new opportunities for blacks to escape from slavery. Some fought for their Revolutionary masters and subsequently gained manumission, while others looked to the British for freedom. In 1775, Virginia's Loyalist Governor Lord Dunmore offered freedom to slaves of Patriot owners if they helped to put down the rebellion. As word of Dunmore's policy of selective emancipation spread, thousands of slaves fled to British lines throughout the colonies. Promised land and provisions (through a series of military proclamations) in one of His Majesty's colonies, the Black Loyalists looked forward to freedom in Nova Scotia and other areas. In 1783, the British evacuated most remaining Loyalists (black and white) from New York. Although the Black Loyalists settled throughout Nova Scotia, the largest group moved to Birchtown nearby Shelburne. The Black Loyalists hoped to become landowning farmers, enjoying the rights accorded other British subjects, but they would be disappointed for two major reasons. First, the majority of the former slaves did not receive land grants. Those who did only obtained paltry allotments that were too small for subsistence. As a result, many African Americans were forced by necessity to enter the wage labor market, while others indentured themselves to wealthy whites. Employers paid the Black Loyalists less money than white workers, which caused an outbreak of economically and racially motivated violence in 1784 . During this riot, local whites attacked black people in Shelburne and destroyed several of their homes. Second, although free and equal subjects of His Majesty in theory, the Black Loyalists were prevented by racist authorities from serving on juries, voting, and regularly received harsh punishments for trivial judicial offenses. During the early 1790s, community leader Thomas Peters petitioned the British government to resettle them in Sierra Leone. As a result, approximately 1,200 Black Loyalists left Nova Scotia 
less than ten years after their original settlement. Accessible published primary sources include, Graham Russell Hodges, (ed.), The Black Loyalist Directory: African Americans in Exile after the American Revolution (New York: Garland, 1996); Ruth Holmes Whitehead and Carmelita A.M. Robertson, (eds.), The Life of Boston King: Black Loyalist, Minister and Master Carpenter (Halifax: Nova Scotia Museum and Nimbus, 2003). The Nova Scotia Archives and Records Management has produced a virtual exhibit with several primary source documents available for viewing. The exhibit also has a searchable database of the "Book of Negroes": http://www.gov.ns.ca/nsarm/virtual/africanns/. Two Nova Scotian women are the subject of the film Loyalties (National Film Board of Canada, 1999), which highlights a black and a white woman attempting to come to terms with their interconnected histories of the Loyalist influx to Nova Scotia. There are Black Loyalist heritage organizations in the Maritimes. Also, there have been archaeological projects related to the Black Loyalists. Needless to say, nothing of this sort, heritage organizations, historical placards, or archaeological projects have been devoted to discovering the history of slavery in Maritime Canada. One recent publication about the Black Loyalists is a work of historical fiction; see Lawrence Hill, The Book of Negroes (Toronto: Harper Collins, Canada, 2007).

9 Neil MacKinnon, This Unfriendly Soil: The Loyalist Experience in Nova Scotia, 1783-1791 (McGill-Queen's University Press, 1986), 53-66; Esther Clark Wright, The Loyalists of New Brunswick (1955, reprint, Moncton: Moncton Publishing Company, 1972).

10 Carole Watterson Troxler, "The Migration of Carolina and Georgia Loyalists to Nova Scotia and New Brunswick," (PhD diss., University of North Carolina, 1974).

11 David Brion Davis, Challenging the Boundaries of Slavery (Cambridge: Harvard University Press, 2003), 1.

12 "Return of the disbanded troops and Loyalists settling in the Province of Nova Scotia, mustered in the summer of 1784," of Robert Morse. This return listed 1232 "servants" and did not list racial identity. It also did not include Shelburne. It is difficult to pin down the exact number of slaves. However, the few histories about slavery in Maritime Canada generally agree that the blacks listed as servants were, in fact, probably slaves.

13 Harvey Amani Whitfield, Blacks on the Border: The Black Refugees in British North America, 1815-1860 (Burlington: University of Vermont Press [University Press of New England], 2006).

14 Adam Rothman, Slave Country: American Expansion and the Origins of the Deep South (Cambridge: Harvard University Press, 2005).

15 T.W. Smith, "The Slave in Canada," Collections of the Nova Scotia Historical Society, 10 (1899): 1-161; William Renwick Riddell, "Slavery in Canada," Journal of Negro History, 5/3 (1920): 261-277; Kenneth Donovan, "Slaves and Their Owners in Ile Royale, 1713-1760," Acadiensis, 25/1 (1995): 3-32; Kenneth Donovan, "Slaves in Ile Royale," French Colonial History, 5 (2004): 25-42; Marcel Trudel, L'esclavage an Canada Francais: Histoire et conditions de l'esclavage (Quebec: Presses de l'Université Laval, 1960); Afua Cooper, The Hanging of Angelique: The Untold Story of Canadian Slavery and the Burning of Old Montreal (Athens: University of Georgia Press, 2007); for the black experience in Prince Edward Island, see Jim Hornby, Black Islanders: Prince Edward Island's Historical Black Community (Charlottetown: Island Studies Institute, 1991); Winks, Blacks in Canada, 24-60, 96-113; Barry Cahill, "Habeas Corpus and Slavery in Nova Scotia: R v. 
Hecht, ex parte Rachel, 1798," University of New Brunswick Law Journal, 44 (1995): 179-209; Barry Cahill, "Slavery and the Judges of Loyalist Nova Scotia," University of New Brunswick Law Journal, 43 (1994): 73-135; D.G. Bell, "Slavery and the Judges of Loyalist New Brunswick," University of New Brunswick Law Journal, 31 (1982): 9-42; Carole Watterson Troxler, "Re-enslavement of Black Loyalists: Mary Postell in South Carolina, East Florida, and Nova Scotia," Acadiensis 37 (2008)70-85; In June 2007, Saint Mary's University held a conference partially devoted to the study of slavery in the Maritimes. I am currently working on a study entitled From Slavery to Slavery: African Americans in Maritime Canada during the Age of Loyalty (under contract, University of Georgia Press).

16 Ira Berlin, Many Thousands Gone: The First Two Centuries of Slavery in North America (Cambridge: Harvard University Press, 1998), 177.

17 Berlin, Thousands, 177.

18 Berlin, Thousands, 178-79; William D. Piersen, Black Yankees: The Development of an AfroAmerican Subculture in Eighteenth-Century New England (Amherst: University of Massachusetts Press, 1988), Appendix; Lorenzo Johnston Greene, The Negro in Colonial New England (1942; reprinted, New York: Atheneum, 1969), 74.

19 Graham Russell Hodges, Root \& Branch: African Americans in New York \& East Jersey, 1613-1863 (Chapel Hill: University of North Carolina Press, 1999), 106.

20 There have been several excellent studies about slavery in the North including, but not limited to, the following works. Greene, Colonial New England; Edgar J. McManus, Black Bondage in the North (Syracuse: Syracuse University Press, 1973); Berlin, Thousands, $177-$ 94; Joanne Pope Melish, Disowning Slavery: Gradual Emancipation and "Race" in New England, 1780-1860 (Ithaca: Cornell University Press, 1998), 1-49; Robert K. Fitts, Inventing New England's Slave Paradise: Master/Slave Relations in Eighteenth Century Narragansett, Rhode Island (New York: Garland, 1998); Robert E. Desrochers, "SlaveFor-Sale Advertisements and Slavery in Massachusetts, 1704-1781," William and Mary Quarterly 59 (July 2002): 623-64; Sarah Deutsch, “The Elusive Guineamen: Newport Slavers, 1735-1774," New England Quarterly 55 (1982): 229-53; Rachel C. Lin, “The Rhode Island Slave-Traders: Butchers, Bakers, and Candlestick-Makers," Slavery and Abolition 23 (December 2002): 21-38; Graham Russell Hodges, Slavery and Freedom in the Rural North: African Americans in Monmouth County, New Jersey, 1665-1865 (Madison: Madison House, 1997), 1-90; Leslie M. Harris, In the Shadow of Slavery: African Americans in New York City, 1626-1863 (Chicago: University of Chicago Press, 2003); Eric J. Roth, " 'The Society of Negroes Unsettled': A History of Slavery in New Paltz, NY," AfroAmericans in New York Life and History 27 (2003): 27-54; Ira Berlin and Leslie M. Harris, eds., Slavery in New York (New York: The New Press, 2005); see Duncan Faherty's review of Berlin and Harris and the exhibit of slavery in New York, "It Happened Here': Slavery on the Hudson," American Quarterly 58 (2006): 455-66; David N. Gellman, Emancipating New York: The Politics of Slavery and Freedom, 1777-1827 (Baton Rouge: Louisiana State University Press, 2006); Thomas J. Davis, "Slavery in Colonial New York City," (PhD diss., 1975); Thelma Wills Foote, Black and White Manhattan: The History of Racial Formation in Colonial New York City (New York: Oxford University Press, 2004); Richard Shannon Moss, Slavery on Long Island: A Study in Local Institutional and Early African American Communal Life (New York: Garland, 1993); Peter Benes, ed., Slavery/Antislavery in New England-The Dublin Seminar for New England Folklife Annual 
Proceedings 2003 (Boston: Boston University, 2005); John Wood Sweet, Bodies Politic: Negotiating Race in the American North, 1730-1830 (Baltimore: Johns Hopkins University Press, 2003); Shane White, "Slavery in the North," Magazine of History 17 (2003): 1721; Thelma Wills Foote, Black and White Manhattan: The History of Racial Formation in New York City (New York: Oxford University Press, 2004); Jill Lepore, New York Burning: Liberty, Slavery, and Conspiracy in Eighteenth-Century Manhattan (New York: Knopf, 2005); also see Brendan McConville's critical review, "Of Slavery and Sources," Reviews in American History 34.3 (2006): 281-90; James Oliver Horton and Lois E. Horton, In Hope of Liberty: Culture, Community and Protest Among Northern Free Blacks, 1700-1860 (New York: Oxford University Press, 1997); Shane White, Somewhat More Independent: The End of Slavery in New York City, 1770-1810 (Athens: University of Georgia Press, 1991); John Saillant, ed., “ 'SOME THOUGHTS ON THE SUBJECT OF FREEING THE NEGRO SLAVES IN THE COLONY OF CONNECTICUT, HUMBLY OFFERED TO THE CONSIDERATION OF ALL FRIENDS TO LIBERTY \& JUSTICE,” by Levi Hart,” 75 (March 2002): 107-28. There have been several dissertations that touch on slavery in the North including, Richard E. Bond, "Ebb and Flow: Free Blacks and Urban Slavery in Eighteenth-Century New York," (PhD diss., Johns Hopkins University, 2005); Catherine Johnson Adams, "What I did Is who I am': African American Women and Resistance to Slavery in Colonial and Revolutionary New England," (PhD diss., University of Illinois at Urbana-Champaign, 2004); Alexandra Antonia Chan, "The Slaves of Colonial New England: Discourses of Colonialism and Identity at the Isaac Royall House, Medford, Massachusetts, 17321775," (PhD diss., Boston University, 2003).

21 Berlin, Thousands, 179.

22 Hodges, Root, 107.

23 Hodges, Root, 107-14; Hodges, Slavery and Freedom, 43-90; Harris, Shadow, 11-47; Peter Benes, "Slavery in Boston Households, 1647-1770," Slavery/ Antislavery in New England (2005): 12-30; Berlin, Thousands, 177-94; Horton and Horton, Liberty, 3-54.

24 Berlin, Thousands, 189-94; Hodges, Root, 115-28; Piersen, Yankees.

25 Horton and Horton, In Hope Liberty, 3-29; Hodges, Root \& Branch, 107-14; Harris, Shadow of Slavery, 30-31; Berlin, Thousands, 179-82

26 Berlin, Thousands, 179.

27 This is not to argue that wealthy Loyalists did not possess slaves. Wealthy Loyalists such as Albany mayor Abraham Cuyler clearly benefited from slave labor. Abraham Cuyler, Loyalist Claims Commission, A.O. 12/19/152, NSARM.

28 Horton and Horton, In Hope of Liberty, 14.

29 On the occupations of the Port Roseway Loyalists, see Minute Book of Port Roseway Associates, NSARM. generally on Barclay, see Hannah D. French, "The Amazing Career of Andrew Barclay, Scottish Bookbinder, of Boston" in Fredson Bowers, ed., Studies in Babliograpby Vol. XIV (Charlottesville: Bibliographical Society of the University of Virginia, 1961. There has been some controversy as to whether Barclay actually owned slaves or simply possessed servants, but the Royal Gazette (New York) of 29 May 1779 mentions Barclay as a slaveholder; the Port Roseway Minute Book lists Barclay as having 5 servants, while another document from Nova Scotia in 1783 indicates he had 7 servants, "Provisional Return for the Numbers of Men, Women, and Children belonging to Captain Andrew Barclay's Company of associated Loyalists," 
July 1783, vol. 220, doc. 1, MG 100, NSARM.

30 Book of Negroes, Guy Carleton Papers, RG 1, NSARM; New-York Gazette; and The Weekly Mercury (New York), 14 February 1780. Totten lists several slaves in his 1788 will and estate inventory, which included a "Negro Boy," "1 Negro Wench," and "3 children." Totten estimated their value in New York currency; see Joseph Totten, 12 March 1788, Annapolis County probate records estate case file T1, NSARM.

31 Minute Book of Port Roseway Associates, NSARM.

32 Book of Negroes, Guy Carleton Papers, RG 1, NSARM. Wall's slaves included Hannah (age 21); Letitia (age 5), and John Thomas (age 15); see the excellent work of Gregory Palmer, Biographical Sketches of Loyalists of the American Revolution (Westport: Meckler Publishing, 1984), 900-01.

33 Book of Negroes, Guy Carleton Papers, RG 1, NSARM; Minute Book of Port Roseway Association, NSARM.

34 Book of Negroes, Guy Carleton Papers, RG 1, NSARM. His slaves were Sam (age twenty two) and Silvia (age thirty); Valentine Nutter File, Shelburne County Archives and Genealogical Society [hereafter SGHS], Shelburne, Nova Scotia.

35 Book of Negroes, Guy Carleton Papers, RG 1, NSARM; Minute Book of Port Roseway Associates, NSARM. The Minute Book lists Lynch as possessing eight servants, while the Book of Negroes indicates that he had at least three slaves and possibly four.

36 This is especially evident in slave advertisements in the Royal Gazette; see Royal Gazette (New York), 5 July 1780; Royal Gazette (New York), 8 March 1783; Royal Gazette (New York), 18 September 1782.

37 Book of Negroes, Guy Carleton Papers, RG 1, NSARM. For example, Henry Guest brought one sixty four year old female slave to Nova Scotia. Mary belonged to David Henry Mallow and settled with him in Shelburne.

38 Harris, Shadow of Slavery, 30

39 Melish, Disowning Slavery, 14.

40 Royal Gazette (New York), 4 March 1780; Royal Gazette (New York), 18 September 1782; Royal Gazette (New York), 12 January 1782; Royal Gazette (New York), 4 July 1781; Royal Gazette (New York), 31 August 1782; Royal Gazette (New York), 2 August 1780.

41 Royal Gazette (New York), 7 June 1780; Royal Gazette (New York), 4 July 1781; Royal Gazette (New York), 12 March 1783.

42 Royal Gazette (New York), 2 August 1780; Royal Gazette (New York), 12 March 1783.

43 Royal Gazette (New York), 26 July 1783.

44 Royal Gazette (New York), 10 May 1780.

45 Royal Gazette (New York), 28 June 1780.

46 Royal Gazette (New York), 8 March 1783.

47 Book of Negroes, Guy Carleton Papers, RG 1, NSARM.

48 Horton and Horton, In Hope of Liberty, 15.

49 Royal Gazette (New York), 5 July 1780.

50 Royal Gazette (New York), 5 August 1780; Royal Gazette (New York), 4 August 1781.

51 Royal Gazette (New York), 9 July 1783.

52 Horton and Horton, In Hope of Liberty, 15.

53 Royal Gazette (New York), 27 July 1782.

54 Royal Gazette (New York), 11 June 1783. 
55 Berlin, Thousands, 180; Hodges, Root \& Branch, 107-14; Hodges, Slavery and Freedom, 4390; Moss, Slavery on Long Island.

56 E.B. O'Callaghan, ed., The Documentary History of the State of New-York Volume 3 (Albany: Weed, Parsons \& Co., 1850), 845-68.

57 David Waldstreicher, "Reading the Runaways: Self-Fashioning, Print Culture, and Confidence in Slavery in the Eighteenth-Century Mid-Atlantic," William and Mary Quarterly 56 (1999): 250-51.

58 Royal Gazette (New York), 7 December 1782.

59 Berlin, Thousands, 177-94.

60 Berlin, Thousands, 182.

61 Hodges, Slavery and Freedom, 49.

62 Hodges, Slavery and Freedom, 45.

63 Hodges, Slavery and Freedom, 47. On the responsibilities of rural slaves, see Hodges, Slavery and Freedom, 44-50.

64 Book of Negroes, Guy Carleton Papers, RG 1, NSARM.

65 Frederick Williams, Loyalist Claims Commission, AO12/23/170. It seems that Williams's female slave and her children died in a fire set by the rebels.

66 John Polhemus, Loyalist Claims Commission, AO12/23/126. Book of Negroes, Guy Carleton Papers, RG 1, NSARM; Petition of John Taylor and others, Negro Proprietors to the General Assembly, December 1807, box 14, doc. 49, RG 5 A, NSARM.

67 Isaac Allen, Loyalist Claims Commission, AO12/16/212; Chipman Papers, Muster Master General's Office, Loyalist Musters, MG 23, D 1, Series I, Volume 24, NSARM.

68 John Francis Ryerson, Loyalist Claims Commission, AO12/15/86.

69 Book of Negroes, Guy Carleton Papers, RG 1, NSARM.

70 James DeLancey, Loyalist Claims Commission, AO12/19/169.

71 George DeLancey Hanger, "The Life of Loyalist Colonel James DeLancey," Nova Scotia Historical Review 3 (1983): 49.

72 Hodges, Slavery and Freedom, 47.

73 Royal Gazette (New York), 12 July 1780; Royal Gazette (New York), 7 June 1780.

74 Royal Gazette (New York), 30 December 1780.

75 Horton and Horton, In Hope of Liberty, 3-29; Harris, In the Shadow of Slavery, 11-47; Berlin, Thousands, 177-94; Melish, Disowning Slavery, 11-49; Piersen, Black Yankees, 14140; Greene, Colonial New England.

76 New Brunswick Reader, 8 January 2000; also see Cynthia Dubin Edelberg, Jonathan Odell: Loyalist Poet of the American Revolution (Durham: Duke University Press, 1987).

77 Hodges, Root \& Branch, 112-13.

78 Hodges, Root \& Branch, 103-07; Berlin, Thousands, 182-84; Harris, Shadow of Slavery, 2930; Deutsch, "The Elusive Guineamen," 229-53; Lin, "The Rhode Island SlaveTraders," 21-38; Steven Deyle, " 'By farr the most profitable trade': Slave Trading in British Colonial North America," Slavery and Abolition 10 (1989): 107-25.

79 Royal Gazette (New York), 20 May 1780.

80 Royal Gazette (New York), 5 July 1780.

81 Royal Gazette (New York), 6 September 1780.

82 Gazette (Boston), 3 March 1777.

83 Royal Gazette (New York), 25 or 26 August 1780. 
84 Royal Gazette (New York), 2 January 1779.

85 Royal Gazette (New York), 10 May 1783.

86 Royal Gazette (New York), 15 June 1783.

87 Royal Gazette (New York), 13 May 1780.

88 Book of Negroes, Guy Carleton Papers, RG 1, NSARM.

89 Berlin, Thousands, 189-94; Hodges, Root Branch, 115-19.

9012 May 1785, Shelburne Records, vol. 141, MG 4, NSARM.

91 On Negro Election Day, see Piersen, Black Yankees, 117-40; Shane White, " 'It Was a Proud Day': African Americans, Festivals, and Parades in the North , 1741-1834," Journal of American History 81 (1994): 13-50; Joseph P. Reidy, "Negro Election Day and Black Community Life in New England, 1750-1860," Marxist Perspectives 1 (1978) 102 17; on Christianity and other cultural beliefs and activities, see Hodges, Root \& Branch, 115-28.

92 Berlin, Thousands, 191.

93 Harris, Shadow of Slavery, 36; also see, Cheryll Ann Cody, “There Was No 'Absalom' on the Ball Plantations: Slave-Naming Practices in the South Carolina Low Country, 17201865," American Historical Review, 92 (June 1987): 563-96; an exploration of African origins among American slaves is John K. Thornton, "Central African Names and African-American Naming Patterns," William and Mary Quarterly, 50 (October 1993): 727-42.

94 Berlin, Thousands, 188.

95 Mechal Sobel, The World They Made Together: Black and White Values in Eighteenth-Century Virginia (Princeton: Princeton University Press, 1987 [1989 paperback edition]), 158.

96 Royal Gazette (New York), 5 July 1780.

97 Book of Negroes, Guy Carleton Papers, RG 1, NSARM.

98 Book of Negroes, Guy Carleton Papers, RG 1, NSARM.

99 Harris, Shadow of Slavery, 36.

100 Book of Negroes, Guy Carleton Papers, RG 1, NSARM.

101 Horton and Horton, In Hope of Liberty, 27.

102 Melish, Disowning Slavery, 45.

103 Piersen, Black Yankees, 25.

104 Book of Negroes, Guy Carleton Papers, RG 1, NSARM.

105 Book of Negroes, Guy Carleton Papers, RG 1, NSARM.

106 Berlin, Thousands, 185.

107 Jennifer Morgan, Laboring Women: Reproduction and Gender in New World Slavery (Philadelphia: University of Pennsylvania Press, 2004); also see the Journal of Women's History (June 2007).

108 Book of Negroes, Guy Carleton Papers, RG 1, NSARM.

109 Hodges, Slavery and Freedom, 50-51.

110 The literature about slavery in the Chesapeake and Lower South is voluminous and includes, but is not limited to the following works. Philip D. Morgan, Slave Counterpoint: Black Culture in the Eighteenth-Century Chesapeake and Lowcountry (Chapel Hill: University of North Carolina Press, 1998); David Eltis, Philip Morgan, and David Richardson, "Agency and Diaspora in Atlantic History: Reassessing the African Contribution to Rice Cultivation in the Americas," American Historical Review 112 (December 2007):1329-58; Berlin, Thousands; Judith A. Carney, The African Origins of Rice Cultivation 
in the Americas (Cambridge: Harvard University Press, 2001); Betty Wood, Gender, Race, and Rank in a Revolutionary Age: The Georgia Lowcountry, 1750-1820 (Athens: University of Georgia Press, 2000); Lorena S. Walsh, From Calabar to Carter's Grove: The History of a Virginia Slave Community (Charlottesville: University Press of Virginia, 1997); William Dusinberre, Them Dark Days: Slavery in the American Rice Swamps (New York: Oxford University Press, 1996); Allan Kulikoff, Tobacco and Slaves: The Development of Southern Cultures in the Chesapeake 1680-1800 (Chapel Hill: University of North Carolina Press, 1986); Lorena S. Walsh, "Work \& Resistance in the New Republic: The Case of the Chesapeake, 1770-1820," in Mary Turner, ed., From Chattel Slaves to Wage Slaves: The Dynamics of Labour Bargaining in the Americas (Bloomington: Indiana University Press, 1995), 105-12; Betty Wood, " Never on a Sunday?': Slavery and the Sabbath in Lowcountry Georgia, 1750-1830," in Mary Turner, ed., From Chattel Slaves to Wage Slaves: The Dynamics of Labour Bargaining in the Americas (Bloomington: Indiana University Press, 1995), 79-94; Lorena S. Walsh, "Slave Life, Slave Society, and Tobacco Production in the Tidewater Chesapeake, 1620-1820," in Ira Berlin and Philip D. Morgan, eds., Cultivation and Culture: Labor and the Shaping of Slave Life in the Americas (Charlottesville: University Press of Virginia, 1993); James Sidbury, Ploughshares into Swords: Race, Rebellion, and Identity in Gabriel's Virginia, 1730-1810 (Cambridge: Cambridge University Press, 1997); Julia Floyd Smith, Slavery and Rice Culture in Low Country Georgia, 1750-1860 (Knoxville: University of Tennessee Press, 1985); Peter Wood, Black Majority: Negroes in Colonial South Carolina from 1670 through the Stono Rebellion (New York: Norton, 1974); Ira Berlin and Ronald Hoffman, eds., Slavery and Freedom in the Age of the American Revolution (Charlottesville: University Press of Virginia, 1983); Sarah S. Hughes, "Slaves for Hire: The Allocation of Black Labor in Elizabeth City County, Virginia, 1782 to 1810," William and Mary Quarterly 35 (April, 1978): 260-86; Lorena S. Walsh, "Rural African Americans in the Constitutional Era in Maryland, 1776-1810," Maryland Historical Magazine 84 (Winter, 1989): 338-39; Joyce E. Chaplin, "Tidal Rice Cultivation and the Problem of Slavery in South Carolina and Georgia, 1760-1815," William and Mary Quarterly 49 (January 1992): 29-61; Lois Green Carr and Lorena S. Walsh, "Economic Diversification and Labor Organization in the Chesapeake, 1650-1820," in Stephen Innes, ed., Work and Labor in Early America (Chapel Hill: University of North Carolina Press, 1988).

111 Rachel Klein, Unification of a Slave State: The Rise of the Planter Class in the South Carolina Backcountry, 1760-1808 (Chapel Hill: University of North Carolina Press, 1990), 20.

112 Morgan, Slave Counterpoint, 59-61.

113 Allan Kulikoff, “A 'Prolifick' People: Black Population Growth in the Chesapeake Colonies, 1700-1790," Southern Studies 16 (1977): 391-428.

114 Berlin, Thousands, 142.

115 Berlin, Thousands, 143.

116 Jean Elliot Russo, “ 'Fifty-Four Days Work of Two Negroes': Enslaved Labor in Colonial Somerset County, Maryland,” Agricultural History 78 (2004): 469.

117 Book of Negroes, Guy Carleton Papers, RG 1, NSARM; James Edward Boisseau, Loyalist Claims Commission, AO12/47/104; Roll of the late South Carolina Royalists at Country Harbour, Nova Scotia, 1784, Chipman Papers, Muster Master General's Office, Loyalist Musters, MG 23, D 1, Series I, Volume 24, pp. 1-470, NSARM.

118 Book of Negroes, Guy Carleton Papers, RG 1, NSARM; also see Chipman Papers, 
Muster Master General's Office, Loyalist Musters, MG 23, D 1, Series I, Volume 24, pp. 1-470, NSARM.

119 James Edward Boisseau, Loyalist Claims Commission, AO12/47/104, NSARM.

120 Memorial of John Saunders (Claim), Military 4-34, Accounting 4-34, Saunders Family Fonds, University of New Brunswick Library, Fredericton, New Brunswick.

121 Berlin, Thousands, 135.

122 Carole Watterson Troxler, “ 'The Great Man of the Settlement': North Carolina's John Legett at Country Harbour, Nova Scotia, 1783-1812," North Carolina Historical Review 67 (1990): 286.

123 John Legett, Loyalist Claims Commission, AO12/35/47, NSARM.

124 Troxler, "John Legett," 285-314.

125 Carole Watterson Troxler, "Origins of the Rawdon Loyalist Settlement," Nova Scotia Historical Review 8 (1988): 62-76; Carole Watterson Troxler, "A Loyalist Life: John Bond of South Carolina and Nova Scotia," Acadiensis 19 (1990): 72-91; Troxler, "John Legett," 285-314.

126 James Alexander, Loyalist Claims Commission, AO13/24/1, NSARM; Book of Negroes, Guy Carleton Papers, RG 1, NSARM.

127 John Hamilton, Loyalist Claims Commission, AO12/47/92, NSARM.

128 Margaret Evans (for her deceased husband), Loyalist Claims Commission, AO12/35/168, NSARM.

129 Donald R. Wright, African Americans in the Colonial Era: From African Origins through the American Revolution (2nd Edition, Wheeling: Harlan Davidson, 2000), 113.

130 Morgan, Slave Counterpoint, 167

131 Morgan, Slave Counterpoint, 147-59.

132 Morgan, Slave Counterpoint, 149.

133 Morgan, Slave Counterpoint, 150.

134 Morgan, Slave Counterpoint, 151.

135 Wright, African Americans, 116.

136 On rice and indigo cultivation, see Morgan, Slave Counterpoint, 147-64.

137 Jacob Ellegood, Loyalist Claims Commission, AO12/54/39, NSARM.

138 Joseph Robinson, Loyalist Claims Commission, AO 12/49/332, NSARM.

139 John Hamilton, Loyalist Claims Commission, AO12/47/92, NSARM.

140 Stair Agnew, Loyalist Claims Commission, AO12/56/138, NSARM.

141 Wright, African Americans, 107.

142 Morgan, Slave Counterpoint, 58-101.

143 Berlin, Thousands, 122.

144 Berlin, Thousands, 122.

145 Berlin, Thousands, 126.

146 Sobel, The World They Made Together.

147 Berlin, Thousands, 128.

148 John Herbert, Loyalist Claims Commission, AO12/55/18, NSARM.

149 Caleb Jones, Folder 14, item 9, 2 pages, Maryland State Papers (Confiscated British Property Papers), 1781-1793, Accession No.: 19990-14-1-1/11, MSA No. S999-15, Maryland State Archives, Annapolis, Maryland.

150 James Dunn, Loyalist Claims Commission, AO12/55/31, NSARM.

151 Book of Negroes, Guy Carleton Papers, RG 1, NSARM. 